Article

\title{
How Does Technology Startups Increase Innovative Performance? The Study of Technology Startups on Innovation Focusing on Employment Change in Korea
}

\author{
Dae Soo Choi ${ }^{1}$, Chang Soo Sung ${ }^{2, *(1)}$ and Joo Y. Park ${ }^{3, *(1)}$ \\ 1 Department of Software Engineering, Joongbu University, Goyang 10279, Korea; daesooc100@gmail.com \\ 2 Department of Technology Entrepreneurship, Dongguk University, Seoul 04620, Korea \\ 3 Discipline of Information Technology, Mathematics, and Statistics, Murdoch University, \\ Murdoch 6150, Australia \\ * Correspondence: redsun44@dongguk.edu (C.S.S.); jooyeon.park@murdoch.edu.au (J.Y.P.)
}

Received: 28 December 2019; Accepted: 9 January 2020; Published: 11 January 2020

\begin{abstract}
As the fourth industrial revolution has been emerging, there are concerns of labor forces being replaced by technology, recent interest on the work-life balance, and the quality of employment has received attention. This study investigates the role of technology startups on employment and innovative performance. Using empirical data from workplace panel data provided by the Korea Labor Institute, this study reveals that technology startups impact the employment quality and innovative performance by the action of technological innovation. The results highlight the quality of employment as a driver for innovative performance in technology startups. The results of this study will provide practical implications for enhancing technology entrepreneurship.
\end{abstract}

Keywords: technology startups; innovative performance; technological innovation; employment quality; employment quantity; entrepreneurship

\section{Introduction}

As the fourth industrial revolution has been emerging, and business models and structures have changed with the advancement of technology, technology startups are receiving attention as playing an important role in employment and innovation. One of the essential motivations in technology startups is a drastic innovation that could result in employment change. Technological innovation has caused job changes in the past industrial revolution, and the concern on the relationship between innovation and employment has been kept in mind. The reason for this concern is that it is important to balance the macroeconomic benefits of technological innovation with the micro(individual) satisfaction of job changes for achieving sustainability and sustainable socio-economic growth. There are also concerns about job changes by technology innovation in that high and advanced technologies, such as artificial intelligence and the internet of things, will be able to replace our physical labor as well as intellectual labor.

Technology startups will bring this phenomenon to reality and draw up the emergence of new jobs and changes in existing ones. Labor for these changes shifts our attention to the quantity of labor, including the unemployment rate, to the qualitative aspects of employment such as education and working hours. That is why not only the quantitative aspect of employment but also the qualitative impact of technology startups on employment is required. Technology startup companies are more focused on technology possession and its utilization based on the substantial degree of understanding of new technology and are generally defined as the creation of products and services through technology 
development [1,2]. The number of research reports has shown the positive effect of technology startups on employment growth and performance [2-6]. However, there are still ongoing debates on whether entrepreneurship impacts employment status. One argues that high unemployment leads to an increase in startups, as called the "refugee effect" while boosting the startups could be the solution to decreasing unemployment rates, so-called "entrepreneurial effect" [7]. The others emphasized that most early SMEs (Small and Medium-sized Enterprises) do not contribute to job creation, noting that startups and young businesses make important contributions to job creation and productivity gains, but that many startup companies do not survive [8].

These arguments raise questions about how technology startups impact employment change and how it leads to innovation. In terms of employment changes, technology startups are expected to affect the quantitative aspects of employment creation, but not many studies have yet talked about the impact of technology startups on the quality of employment. Moreover, there is little research that has examined innovation as an output concerning employment. To respond to the research questions on what role technology startups could play in terms of employment and innovation, this study will represent the following purposes. First, the impact of technology startups on employment change in terms of both quantitative and qualitative aspects will be identified. Second, the influence of employment change on innovative performance will be discussed. Third, the technological innovation in both product and process innovation of technology startup companies will also be identified regarding employment change. To achieve the purpose of this study, data that are officially investigated and published by the Korean government are reviewed. The data include the results of a survey that can measure both technological innovation and the quantitative and qualitative aspects of employment of each firm. Therefore, it is judged to be the most suitable data to investigate the research purposes as well as to construct and analyze with regression models. The results of this research provide insights into how technology startups play a role in economic growth with employment and innovation. Also, the study on the qualitative aspect of the jobs created by technological entrepreneurship could help to gauge the future jobs of technology entrepreneurs.

\section{Literature Review}

\subsection{Technology Startups and Employment Change}

Technology startup companies are defined in various ways, but it predominately involves the understanding of technology and the creation of products and services with the technology $[3,9]$. However, it also involves the possession of technology or the process of value creation through technology regardless of direct technology development [1]. Technology startup companies also have been classified by R\&D intensity and the weight of intangible assets [10]. The process of a technology startup is defined as the development of specialized technical knowledge and investment in technical assets for creating and acquiring value for the enterprise [2]. A technology startup is considered a source of employment in that it usually generates new products and services that will lead to new demand and highly skilled labor that requires new jobs to fulfill. According to the general theory of employment by John Maynard Keynes [11], the cause of unemployment can be explained as insufficient effective demand, and the emergence of new products and services created from startup companies can be an important reason to generate effective demand and to increase employment.

The studies of the impact of technology startups on employment mostly have focused on the role of job creation $[6,8,12]$. One study showed that job creation turned out to be higher in knowledge services sectors than manufacturing industries [13]. That is, high-technology startup companies are likely to contribute to the increase in employment compared to the low-technology companies. Also, Kim et al.'s research analyzed the change in the annual average employment growth rate of startups with a higher level of technology to identify the factors contributing to employment creation [10]. The research revealed that technology startups have a relatively higher level of employment growth rate than that of other non-technology startups. Fritsch and Mueller analyzed, using a dynamic time 
series analysis, the effects of startup rates on employment growth based on German statistics [4]. Their research found that there was a direct effect on the employment increase of startups in the early stages, and there was a displacement effect in the mid- and long-term phases, which meant a restructuring of employment was caused by the entry of startups. In the long run, however, it has shown that startups can induce employment, which causes more employment. Acs and Mueller also found that the employment-creation effect of entrepreneurship occurs primarily within one year [5], and thus, technology startups in early stages will affect the increase in employment. Moreover, a number of researchers have emphasized that there are entrepreneurial effects that decrease unemployment rates and are encouraging for startup companies [7,14].

There has been increasing interest in the qualitative aspects of employment, as technology has been pervasive and replaced the workforce, and research has been actively conducted on the quality of jobs or decent jobs [15-17]. Some of the factors that make up the quality of employment are those related to innovation, such as education, training, and development. Employment quality has been measured differently by different researchers, but it mostly includes conditions such as wage level, employment stability, vocational training and development potential, career opportunities, working hours, social security, workplace family balance, and organizational commitment [17].

\subsection{Employment Change and Innovation}

Technological innovation refers to a change that creatively destroys the balance of the market and is possible through a new combination [18]. Examples of technological innovation include the introduction of new products and devices, the introduction of new production methods, and creating new forms of the organizational process. Most of the previous studies have shown a positive relationship between innovation and employment, especially product and process innovation [19-22]. However, the relationship between innovation and employment is explained from many perspectives. First, a lot of the existing workforce is reduced by innovation, and new jobs are created with laid-off workers in new technology areas. The second view is that if the process of innovation reduces the price of the product, and thus creates new demand, then production will need to be increased, and additional labor will be required to create employment. Third, innovation creates new jobs by generating new corporate investment, and allocations of the performance of technological advancement lead to increased worker income, which, in turn, leads to an increase in employment and consumption [20,21,23].

Technology startups are defined in many prior studies around innovation, which, in turn, can lead to higher performance for the startup business through innovation [24-26]. Thus, innovation in technology startups can be interpreted as both a process and a result. That is one of the reasons that many technology startup companies try to offer their employees lots of benefits and better job conditions. A recent study found that the better the treatment of employees by the companies, the more innovative the outcomes were [27]. The study by Chen et al. revealed that there is a strong, positive relationship between worker treatment and innovation, which was measured as the number of patents in this study [27]. Companies with better worker treatment regarding safety, employee relations, and diversity produce more relevant patents, even better than those with lots of expertise. The study of employee friendliness and innovation by Adhikari et al. also suggested that cash profits and employee involvement have a positive impact on the innovation output of a firm [28]. In aligning with the fact that the more satisfied employees the better the productivity of a firm, the results of this study stress that employee-friendly policies elevate employee power in increasing the innovation productivity.

Employment quality is related to a decent job that could lead to better performance in organizations. Previous researchers have shown that the quality of employment has a positive effect on most organizational performances in terms of financial performance and labor productivity [29]. It has also been proven that education, one of the components of the quality of employment, has a significant impact on regional development through new business creation [30]. Based on the analysis of substantial years of panel data, Lachenmaier and Rottmann demonstrated the impact of innovation on employment, not only with innovation as an input but also as an output [31]. Their research showed 
that innovation has a positive effect on employment in the first lag of innovation expenditure, while innovation outputs turned out positive effects in the second lag. This indicates there is a link between employment change and innovation output in terms of the productivity growth generated by a higher level of employment quality.

\section{Hypothesis Development}

In terms of education/training as well as the level of wages and welfare benefits, technology startups that are promoting innovation in products and services through extensive technology and knowledge can be expected to invest a lot in education and training. In the same vein, innovation activities induce a change in the skill structure of employees to the increasing demand for highly skilled labor [32]. Hamermesh also mentioned technological change would be demanding for highly skilled laborers [33]. Frydman and Papanikolaou argued that compensation is higher in high-tech firms such as technology startup companies where value is brought to identifying new innovative opportunities [34]. That is, the shifting of new business frames and fast-growing firms requires skills to identify new opportunities and discovering new technology; thus, this increases the compensation of related executives and workers. Thus, compensation and welfare benefits are supposed to be higher in technology startups than that in non-technology startup companies. With these discussions, the following hypotheses have been set.

Hypothesis 1. Technology startups have higher employment (quality/quantity).

Hypothesis 1a (H1a). Technology startups have higher employment quality.

Hypothesis $\mathbf{1 b}$ (H1b). Technology startups have higher employment quantity.

Lachenmaier and Rottmann studied the relationship between innovation and employment with 20 years of long panel data and showed that there were positive effects of innovation on employment [31]. The study of Hong et al. on innovation and employment explained that innovation activities lead to increased productivity and, thus, lead to job creation through business growth [35]. Innovation can be mainly divided into product innovation and process innovation. That is, employment creation takes place through product innovation that will lead to a generation of new demands and additional employment. Process innovation is also able to increase the quality and productivity that will generate employment creation. The study of innovation policy on SME employment supported these arguments in that both product and process innovation have a high impact on employment growth [36]. Yang and Shao argued that skill-based technological advances improve efficiency and productivity growth, which links to industrial growth and market demand creation as well as employment demands [37]. Thus, the following hypothesis has been made.

Hypothesis 2. The impact of technology startups on employment change is moderated by the degree of technological innovation (product, process).

Janmandreu also proposed a relationship between employment growth and innovation output [38]. Moreover, the positive relationship between employment and innovation has been found in terms of labor laws and financial perspectives. Studies have shown that when the labor law of protecting from dismissing workers is imposed, innovation is increased, and the employees who were offered stock options were more innovative $[39,40]$. Lin et al. also examined the relationship between managerial incentives and CEO characteristics on a firm's innovation based on the data from China's private sector. They discovered that managerial incentives and the executive's education level are the factors that increase both innovation efforts and innovation performance of a firm [41]. Overall, it is suggested that treating employees well by offering incentives and enhancing employment quality is one way to improve innovative performance, as too much pressure on delivering results may lead to workers 
reluctant to pursue innovation that oftentimes could be uncertain and even risky [42]. Therefore, the employment change in quality and quantity can influence innovative performance.

Hypothesis 3. The employment (quality/quantity) is positively associated with innovative performance.

Hypothesis 3a (H3a). The employment quality is positively associated with innovative performance.

Hypothesis $\mathbf{3 b} \mathbf{b} \mathbf{H} 3 \mathbf{b})$. The employment quantity is positively associated with innovative performance.

A regression analysis model is constructed to analyze the research hypotheses with datasets obtained from government agencies. The detailed measurement and hypothesis verification procedures are described in the following section.

\section{Methodology}

\subsection{Samples}

The workplace panel data provided by the Korea Labor Institute was used for the analysis of this research model. The workplace panel survey is an end-to-end survey with 3400 Korean businesses that tracks information about the overall business environment and human resources management system, the status of labor-management relations, and wage negotiations once every two years. The detailed survey consists of questions on the status of workers, financial status, workplace characteristics, employment status and employment management, compensation and evaluation, human resource management and work organization, human resources development, business welfare, health and labor relations, and so forth. [43]. The purpose of the survey is to identify the employment structure of the unit of business, human resource management, labor-management relations, and the status of human resource development, and to use them for research on employment problems and policy development. The workplace panel data are consistent with the purpose of this study because it includes not only data on the employment status and financial status of workers, which can analyze the quantitative performance of employment, but also data to identify the quality aspects of employment such as employee management, compensation and evaluation, human resources management, labor relation, corporate welfare, and so forth.

The primary data from 608 companies were used in the research analysis. As described in Table 1, there were 608 companies in the manufacturing industry, accounting for $38.7 \%$, and 322 were businesses, accounting for $52.8 \%$. A total of 37 companies were classified in the construction industry, while 7 companies each were included in the electricity and gas suppliers sector as well as the water, sewer, and waste sector. Industry classification was based on the classification of the 9th Korea standard industrial classification system provided by the business panel survey [43].

Table 1. Classification of sample companies.

\begin{tabular}{ccc}
\hline Sectors & Frequency & \% \\
\hline Manufacturing & 235 & 38.7 \\
Service & 322 & 52.8 \\
Construction & 37 & 6.1 \\
Electricity and gas supply & 7 & 1.2 \\
Water, sewer, waste & 7 & 1.2 \\
Sum & 608 & 100 \\
\hline
\end{tabular}

\subsection{Measurement Variables}

In order to identify technology startup companies, two criteria were set: one is if the company was less than 7 years old, and the other is where it possesses certain technology and knowledge. Startup companies were defined as those within seven years of their establishment date, as suggested in the Small Businesses Startup Support Act [44]. The status of technology possession was classified based 
on the intangible assets ratio and technology level. The high-tech sector and technology sector were included in the category of technology firms by referring to the Bank of Korea's "Business Analysis Technology Level Classification". Knowledge-intensive industries were also added to the technology startup analysis. Detailed criteria for the definition of technology startups are shown in Appendix A.

Employment change was measured in two dimensions: one is employment quantity measured as the number of employees, and the other is employment quality which includes six factors based on the existing standards provided by the International Employment Organization in the European Union [45]. The factors are wage level, employment stability, education and training, working hours, social security, and work-family balance. Table 2 describes the definition and measurement of each variable used in this research.

Table 2. Description of variables.

\begin{tabular}{|c|c|c|c|}
\hline Variable & Description & Measurement & Source \\
\hline \multirow[t]{2}{*}{ Technology startups } & \multirow{2}{*}{$\begin{array}{l}\text { Startups conduct business } \\
\text { through technology acquisition or } \\
\text { startups of the industry where the } \\
\text { role of technology is important. }\end{array}$} & $\begin{array}{l}\text { Startups with a higher average intangible assets } \\
\text { ratio or startups in high-tech manufacturing } \\
\text { and knowledge-intensive industries }\end{array}$ & {$[2,9]$} \\
\hline & & Companies less than 7 years old & {$[44]$} \\
\hline Employment quality & Qualitative level of decent jobs & $\begin{array}{l}\text { Index derived from the following items (wage } \\
\text { level, employment stability, education training, } \\
\text { working hours, social security and benefits, and } \\
\text { work-family balance) }\end{array}$ & {$[15,16,29]$} \\
\hline Employment quantity & $\begin{array}{l}\text { Quantitative level of job creation } \\
\text { and retention }\end{array}$ & $\begin{array}{l}\text { Number of employees with annual } \\
\text { sales comparison }\end{array}$ & {$[4,5]$} \\
\hline $\begin{array}{l}\text { Technological Innovation } \\
\text { (Product, Process) }\end{array}$ & $\begin{array}{l}\text { The creative destruction of market } \\
\text { balance through the introduction } \\
\text { of new products and processes }\end{array}$ & $\begin{array}{l}\text { The status of product/process innovation in } \\
\text { the year }\end{array}$ & {$[18,46]$} \\
\hline
\end{tabular}

\section{Result}

\subsection{Measurement Analysis}

The weighting of the selected indicators in this study was based on a principal component analysis to exclude subjectivity. First, weights were assigned to each item by principal component analysis for each index, and the score of the index was calculated. At this time, the values of each index were converted to values between 0 and 1 through normalization. Therefore, the function to obtain the quality index of employment (hereafter referred to as the employment quality index) is derived as follows:

$$
\mathrm{QEI}=0.12 \mathrm{Q} 1+0.13 \mathrm{Q} 2+0.2 \mathrm{Q} 3+0.22 \mathrm{Q} 4+0.2 \mathrm{Q} 5+0.13 \mathrm{Q} 6
$$

where $\mathrm{Q} 1$ = wage level, $\mathrm{Q} 2$ = employment stability, $\mathrm{Q} 3$ = education and training, $\mathrm{Q} 4$ = working hours, Q5 = social security and benefits, and Q6 = work-family balance.

Table 3 demonstrates the descriptive statistics for the variables used in this research, and Table 4 depicts the correlation of variables used in this study indicating that the validity of variables was acceptable.

Table 3. Descriptive statistics.

\begin{tabular}{ccccc}
\hline Variable & Min & Max & Mean & Std. Dev. \\
\hline Employment Quantity Index & 1.922 & 208.351 & 15.41 & 23.62 \\
Employment Quality Index & 2.033 & 5.000 & 3.49 & 0.48 \\
Product Innovation & 1.00 & 5.00 & 1.54 & 1.367 \\
Process Innovation & 1.00 & 5.00 & 1.47 & 1.286 \\
Innovative Performance & 1.00 & 5.00 & 1.50 & 1.329 \\
\hline
\end{tabular}


Table 4. Correlation matrix.

\begin{tabular}{|c|c|c|c|c|c|c|c|c|c|c|c|c|}
\hline Variable & A & B & $\mathrm{C}$ & D & $\mathrm{E}$ & $\mathbf{F}$ & G & $\mathbf{H}$ & $\mathbf{I}$ & $\mathbf{J}$ & K & $\mathbf{L}$ \\
\hline A. Technology startups & 1 & -0.094 & $0.164^{* *}$ & $0.172 * *$ & 0.079 & 0.099 & -0.031 & 0.053 & $0.151^{* *}$ & 0.059 & 0.087 & 0.095 \\
\hline B. Employment quantity index & -0.094 & 1 & $0.115 *$ & -0.060 & -0.035 & $0.185^{* *}$ & 0.089 & 0.092 & 0.101 & 0.040 & -0.017 & 0.030 \\
\hline C. Employment quality index & $0.164 * *$ & $0.115 *$ & 1 & $0.621 * *$ & $0.312^{* *}$ & $0.575^{* *}$ & $0.278^{* *}$ & $0.725^{* *}$ & $0.698^{* *}$ & 0.038 & 0.083 & 0.109 \\
\hline D. Wage level & $0.172 * *$ & -0.060 & $0.621^{* *}$ & 1 & 0.005 & $0.204^{* *}$ & 0.031 & $0.368^{* *}$ & $0.284^{* *}$ & 0.033 & 0.086 & 0.073 \\
\hline E. Employment stability & 0.079 & -0.035 & $0.312 * *$ & 0.005 & 1 & 0.170 ** & 0.031 & $0.145^{* *}$ & 0.091 & -0.009 & -0.030 & -0.017 \\
\hline F. Education training & 0.099 & $0.185^{* *}$ & $0.575^{* *}$ & $0.204^{* *}$ & $0.170 * *$ & 1 & 0.022 & 0.323 ** & $0.281 * *$ & 0.054 & $0.179^{* *}$ & $0.172 * *$ \\
\hline G. Working hours & -0.031 & 0.089 & $0.278^{* *}$ & 0.031 & 0.031 & 0.022 & 1 & 0.029 & 0.135 * & -0.092 & -0.115 * & -0.100 \\
\hline H. Social security and benefits & 0.053 & 0.092 & $0.725^{* *}$ & $0.368^{* *}$ & $0.145^{* *}$ & $0.323 * *$ & 0.029 & 1 & $0.282 * *$ & 0.055 & 0.049 & 0.091 \\
\hline I. Work-family balance & $0.151 * *$ & 0.101 & $0.698^{* *}$ & 0.284 ** & 0.091 & $0.281^{* *}$ & $0.135 *$ & $0.282^{* *}$ & 1 & 0.034 & 0.054 & 0.081 \\
\hline J. Product innovation & 0.059 & 0.040 & 0.038 & 0.033 & -0.009 & 0.054 & -0.092 & 0.055 & 0.034 & 1 & $0.521 * *$ & $0.787^{* *}$ \\
\hline K. Process innovation & -0.087 & -0.017 & 0.083 & 0.086 & -0.030 & $0.179 * *$ & $-0.115^{*}$ & 0.049 & 0.054 & $0.521 * *$ & 1 & 0.857 ** \\
\hline L. Innovative performance & 0.095 & 0.030 & 0.109 & 0.073 & -0.017 & $0.172 * *$ & -0.100 & 0.091 & 0.081 & $0.787 * *$ & $0.857 * *$ & 1 \\
\hline
\end{tabular}


The quality of employment consists of multiple factors such as wage, employment stability, education training, working hours, benefits, and work-family balance. Table 5 shows the results of the correlation analysis for the factors that constitute the quality of employment.

Table 5. Employment quality index correlation (Pearson correlation coefficient).

\begin{tabular}{ccccccc}
\hline Factor & $\begin{array}{c}\text { Wage } \\
\text { Level }\end{array}$ & $\begin{array}{c}\text { Employment } \\
\text { Stability }\end{array}$ & $\begin{array}{c}\text { Education } \\
\text { Training }\end{array}$ & $\begin{array}{c}\text { Working } \\
\text { Hours }\end{array}$ & $\begin{array}{c}\text { Social Security } \\
\text { Benefits }\end{array}$ & $\begin{array}{c}\text { Work-Family } \\
\text { Balance }\end{array}$ \\
\hline Wage level & 1 & 0.005 & $0.204^{* *}$ & 0.031 & $0.368^{* *}$ & $0.284^{* *}$ \\
Employment stability & 0.005 & 1 & $0.170^{* *}$ & 0.031 & $0.145^{* *}$ & 0.091 \\
Education training & $0.204^{* *}$ & $0.170^{* *}$ & 1 & 0.022 & $0.323^{* *}$ & $0.281^{* *}$ \\
Working hours & 0.031 & 0.031 & 0.022 & 1 & 0.029 & $0.135^{*}$ \\
Social security benefits & $0.368^{* *}$ & $0.145^{* *}$ & $0.323^{* *}$ & 0.029 & 1 & $0.282^{* *}$ \\
Work-family balance & $0.284^{* *}$ & 0.091 & $0.281^{* *}$ & $0.135^{*}$ & $0.282^{* *}$ & 1 \\
\hline
\end{tabular}

** correlation coefficient is significant at 0.01 level. ${ }^{*}$ correlation coefficient is significant at 0.05 level.

Following the approach to Hagedoorn and Cloodt [46], the innovative performance as a dependent variable was measured with the innovative outcomes of a firm's activities in a certain year. Technological innovation as a moderating variable was measured with the level of product innovation and process innovation. The correlation of these variables is shown in Table 6.

Table 6. Innovation index correlation (Pearson correlation coefficient).

\begin{tabular}{cccc}
\hline Variable & Product Innovation & Process Innovation & Innovative Performance \\
\hline Product Innovation & 1 & $0.521^{* *}$ & $0.787^{* *}$ \\
Process Innovation & $0.521^{* *}$ & 1 & $0.857^{* *}$ \\
Innovative Performance & $0.787^{* *}$ & $0.857^{* *}$ & 1 \\
\hline
\end{tabular}

${ }^{* *}$ correlation coefficient is significant at 0.01 level.

\subsection{Hypothesis Analysis}

To investigate the extent of employment quality and quantity based on whether or not the company was a technology startup, a regression analysis using SPSS 20 was conducted. It shows that the impact of technology startups on the quality of employment was significant, with $p=0.045$, but its impact on the quantity of employment was not significant $(t=-1.687 ; p=0.093)$. Therefore, H1a was supported, but not H1b (Table 7).

Table 7. Multiple regression analysis. (H1a, H1b).

\begin{tabular}{|c|c|c|c|c|c|c|c|c|}
\hline & \multirow{2}{*}{ Model } & \multicolumn{2}{|c|}{$\begin{array}{l}\text { Non-Standardization } \\
\text { Factor }\end{array}$} & \multirow{2}{*}{$\begin{array}{c}\begin{array}{c}\text { Standardization } \\
\text { Factor }\end{array} \\
\text { Beta } \\
\end{array}$} & \multirow[t]{2}{*}{ t } & \multirow{2}{*}{$\begin{array}{l}\text { Probability of } \\
\text { Significance }\end{array}$} & \multicolumn{2}{|c|}{ Collinearity Statistic } \\
\hline & & B & Standard Error & & & & Tolerance & VIF \\
\hline \multirow{2}{*}{ H1a } & Constant & 3.445 & 0.028 & - & 121.734 & 0.000 & - & - \\
\hline & $\begin{array}{l}\text { Employment } \\
\text { Quality }\end{array}$ & 0.079 & 0.039 & 0.081 & 2.010 & 0.045 & 1.000 & 1.000 \\
\hline \multirow{2}{*}{$\mathrm{H} 1 \mathrm{~b}$} & Constant & 18.092 & 2.066 & - & 8.759 & 0.000 & - & - \\
\hline & $\begin{array}{l}\text { Employment } \\
\text { Quality }\end{array}$ & -4.533 & 2.686 & -0.094 & -1.687 & 0.093 & 1.000 & 1.000 \\
\hline
\end{tabular}

H1a-dependent variable: employment quality, $\mathrm{R}=0.081$, R-square $=0.007$, adjusted R-square $=0.005, \mathrm{~F}=4.039$, $p=0.045$, Durbin-Watson $=1.850$. H1b-dependent variable: employment quantity, $\mathrm{R}=0.094$, $\mathrm{R}$-square $=0.009$, adjusted R-square $=0.006, \mathrm{~F}=2.847, p=0.093$, Durbin-Watson $=0.052$.

A three-step model was constructed to analyze the moderating effects, and a procedure was conducted to determine whether the model's explanatory power increased within a significant range.

Model 1: dependent variable $\leftarrow$ independent variable 
Model 2: dependent variables $\leftarrow$ independent variables, control variables

Model 3: dependent variable $\leftarrow$ independent variable, controlled variable, interaction variable

As seen in Table 8, for the moderating effect of product innovation on the relationship between technology startup and the quality of employment, R-square increased and had a significant probability smaller than 0.05 . However, the moderating effect of process innovation exceeded the appropriate level.

Table 8. Moderating effects of quantitative aspects of employment.

\begin{tabular}{ccccccccccc}
\hline $\begin{array}{c}\text { Innovation } \\
\text { Type }\end{array}$ & Model & $\mathbf{R}$ & $\begin{array}{c}\mathbf{R} \\
\text { Square }\end{array}$ & $\begin{array}{c}\text { Adjusted } \\
\text { R Square }\end{array}$ & $\begin{array}{c}\text { Standard Error } \\
\text { of Estimate }\end{array}$ & $\begin{array}{c}\mathbf{R} \\
\text { Square }\end{array}$ & $\begin{array}{c}\text { F } \\
\text { df1 }\end{array}$ & $\begin{array}{c}\text { Statistic Variation } \\
\text { df2 }\end{array}$ & $\begin{array}{c}\text { Probability of } \\
\text { Significance }\end{array}$ \\
\hline Product & 1 & $0.081^{\mathrm{a}}$ & 0.007 & 0.005 & 0.481901 & 0.007 & 4.039 & 1 & 606 & 0.045 \\
Innovation & 2 & $0.087^{\mathrm{b}}$ & 0.008 & 0.004 & 0.482086 & 0.001 & 0.537 & 1 & 605 & 0.464 \\
& 3 & $0.123^{\mathrm{c}}$ & 0.015 & 0.010 & 0.480604 & 0.008 & 4.736 & 1 & 604 & 0.030 \\
\hline Process & 4 & $0.081^{\mathrm{d}}$ & 0.007 & 0.005 & 0.481901 & 0.007 & 4.039 & 1 & 606 & 0.045 \\
Innovation & 5 & $0.099^{\mathrm{e}}$ & 0.010 & 0.007 & 0.481527 & 0.003 & 1.943 & 1 & 605 \\
\hline
\end{tabular}

a. Forecast value: (constant), product innovation. b. Estimates: (constant), product innovation, employment quality. c. Estimates: (constant), product innovation, employment quality, control variables. d. Forecast value: (constant), process innovation. e. Estimates: (constant), process innovation, employment quality. f. Estimates: (constant), process innovation, employment quality, control variables.

The regression analysis for the effects of the quality and quantity of employment on organizational innovation revealed that employment quality was significantly related to organizational innovation, with $p<0.05(t=2.229 ; p=0.026)$, while the effect of employment quantity on organizational innovation was not significant $(\mathrm{t}=0.534 ; p=0.594)$. Therefore, H3a was supported, but $\mathrm{H} 3 \mathrm{~b}$ was not supported (Table 9).

Table 9. Multiple regression analysis. (H3a, H3b).

\begin{tabular}{|c|c|c|c|c|c|c|c|c|}
\hline & \multirow{2}{*}{ Model } & \multicolumn{2}{|c|}{$\begin{array}{c}\text { Non-Standardization } \\
\text { Factor }\end{array}$} & \multirow{2}{*}{$\begin{array}{c}\begin{array}{c}\text { Standardization } \\
\text { Factor }\end{array} \\
\text { Beta }\end{array}$} & \multirow{2}{*}{$\mathbf{t}$} & \multirow{2}{*}{$\begin{array}{l}\text { Probability of } \\
\text { Significance }\end{array}$} & \multicolumn{2}{|c|}{ Collinearity Statistic } \\
\hline & & B & Standard Error & & & & Tolerance & VIF \\
\hline Н3а & $\begin{array}{c}\text { Employment } \\
\text { Quality }\end{array}$ & 0.197 & 0.088 & 0.090 & 2.229 & 0.026 & 1.000 & 1.000 \\
\hline
\end{tabular}

H3a-dependent variable: innovative performance, $\mathrm{R}=0.090$, $\mathrm{R}$-square $=0.008$, adjusted R-square $=0.006, \mathrm{~F}=4.968$, $p=0.026$, Durbin-Watson $=0.024$. H3b-dependent variable: innovative performance, $\mathrm{R}=0.030$, $\mathrm{R}$-square $=0.001$, adjusted R-square $=0.002, \mathrm{~F}=0.285, p=0.594$, Durbin-Watson $=2.027$.

The results of the hypothesis test are summarized in Table 10 below. As expected, there was a strong relationship between technology startups and the quality of employment (H1a), and its relationship was moderated by technological innovation, specifically product innovation. Moreover, the relationship between employment quality and innovative performance was also accepted (H3a). However, unlike the hypothesis, the result showed the relationship of technology startups with the quantity of employment and innovative performance was rejected (H1b; $\mathrm{H} 3 b)$. 
Table 10. Summary of hypothesis verification results.

\begin{tabular}{cc}
\hline Hypothesis & Result \\
\hline H1a: Technology startups have higher employment quality. & Accept \\
H1b: Technology startups have a higher employment quantity. & Reject \\
technological innovation (product, process). & Partial \\
H2: The impact of technology startups on employment is moderated by the level of & Accept \\
H3a: The employment quality is positively associated with innovative performance. & Accept \\
H3b: The employment quantity is positively associated with innovative performance. & Reject \\
\hline
\end{tabular}

\section{Implications}

In the rapidly changing digital environment, employment status will be changed, and technology startups will play a great role in enhancing the human-centered quality of employment. This research proposed employment change generated by technology startups and its impact on innovation. This research also provided an opportunity to stress the importance of employment quality in technology startups that could enhance innovative performance. Additional analysis of employment quality by years also represented a higher level of employment quality in technology startups. As shown in Figure 1, with the exception of the downward trend in 2009 (the period of decline in corporate growth due to the global financial crisis), technology startups showed a higher quality of employment than that of general startup companies.

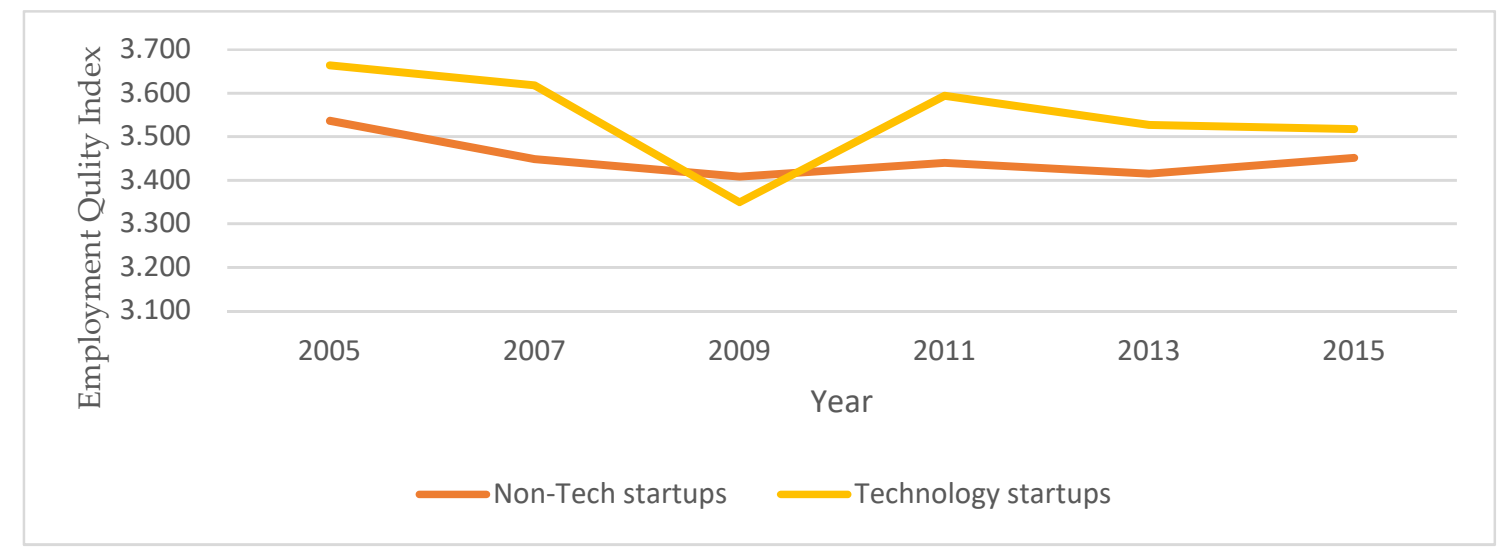

Figure 1. Employment quality between technology startups and non-tech startups.

The result of this study implies that technology startups have a higher level of employment quality in workplaces compared to other non-technology startup companies, and the innovative performance can be better with a higher employment quality. Thus, this study suggests that the concerns of unemployment and insecure labor forces by environment changes could be resolved by enhancing technology startup companies. This result is similar to the discussion of Aldieri and Vinci, arguing that economic crisis could be an opportunity for all firms to invest more in innovation to improve their competitiveness, develop new external knowledge, and eventually benefit all workers [47].

Moreover, this study provides empirical analyses of the relationship between employment and innovation using workplace panel data. The empirical analysis of employment and innovation is meaningful in that economic theory cannot clearly explain them, and the theoretical approach is not able to consider various conditions and variables that might affect the relationship [21].

The results of this research suggest a number of implications for policymakers and practitioners. First, governments have been promoting and implementing new technologies, and they support startup companies and SMEs as a means to increase competitiveness and increase employment. However, it is still in question whether policy and support effectively achieve this goal in terms of employment and innovation. In the same view from the study by Castillo et al. [36], the result of this study has also 
shown the positive effects of technology startups on employment quality and innovation. This finding confirms that government support and implementation for technology startups are positively effective, as expected in innovation and employment, and thus it leads to economic growth.

Second, this study implies that technological entrepreneurship and technological innovation have a positive effect on the quality of employment. The results of this study support the argument that the activation of technological innovation activities leads to the creation of high-quality employment. Although, unlike the expectation, technology startups have failed to increase the number of employees, and it assumes that technology startups provide a higher level of employee wages, benefits, and satisfaction with increasing sales demand by product and process innovation. Thus, as suggested by Bogliacino [48], policies supporting technology startups should be monitored carefully in terms of the innovation activities and employment quality provision. Third, the results of this study demonstrate that employment-friendly and higher-quality employment support firms are likely to induce higher innovation. This is in line with previous research, in that the better employees are treated, the more innovative their performance $[27,49]$. It is a virtuous cycle of technology startups providing decent job conditions that will lead to innovative performance and vice versa. This result also implies that investment and support of technology startups are effective ways of increasing employment and innovation.

\section{Conclusion and Future Research}

This study aimed to examine the important role of technology entrepreneurship in the fast-moving, high-tech forth revolutionary industry. As expected, technology startup companies provide a lot of advantages and economic growth as they serve with higher employment status and more innovative activities. In consequence, technology startups have a crucial role in leading higher sales demands and economic profits.

It is expected that the meaning and nature of labor have been modified and will change drastically due to the fourth industrial revolution. More changes are expected than those caused by the industrial revolution in the past, and concerns about job cutbacks are becoming serious. For example, we are witnessing that artificial intelligence is doing a great deal of work that we thought was already creative, and humans are looking for tasks that require a higher level of creativity that artificial intelligence cannot solve. Therefore, the meaning and direction of new labor and employment need to be established. The work of new meaning created by such tasks should be of high quality that can enrich human life above all. In this respect, the fact that technology startups, which are continuously emphasized to strengthen our competitiveness, create high-quality jobs and, in turn, increase innovation performance is strongly encouraging, and this needs to be strongly supported by related policy and support by governments and institutions. Moreover, technological innovations that are faster than before continue to create new values. The quality of jobs changing in this process, fortunately, turns out to be positive. In other words, the positive sign of employment quality by technology startups implies that technology entrepreneurs and technology innovations contribute to changing the way people are satisfied with their jobs. Employment and innovation are important factors in improving the economic and social sustainability of human beings. Thus, enhancing employment quality with technology innovation is meant to be important in innovating performance as well as in leading a virtuous circle of sustainable economic growth. The results of this study, therefore, show meaningful implications.

In conclusion, this study presented a different view of the argument that technology will replace human jobs by suggesting an increase in employment quality by technology startups. Moreover, in responding to the recent attention on the work-life balance, the result that technology startups improve employment quality suggests a significant implication in terms of labor innovation. It is also significant that technology startups are not only positive about the quality of employment but can also create other innovations through innovative activities and employment quality. Rather than focusing on revitalizing startups as a means of employment, it is necessary to focus on boosting startups as players of creating better economic growth and a business ecosystem. 
Even though this research provides significant insights regarding the role of technology startups on employment change and innovation, a couple of research limitations are suggested to improve future research. First, as stated by Lachenmaier and Rottmann [31], the increase in employment change and innovation should be measured with longitudinal datasets and examined with time lags. However, this research investigated empirical data only in a certain period of time with regression analysis to focus on the relationship among variables. Thus, it is suggested that a time series analysis could be applied to examine the changes in employment over time and the actual innovation outputs as firms grow. Second, the measurement of innovation outcomes involves various factors such as a firm's characteristics, the manager's education and networking level, and industrial sectors. Therefore, one should be careful in analyzing the innovation outcomes as controlling related variables. Lastly, the data only demonstrated the domestic situation regarding technology startups, innovation, and employment. It would be interesting to research comparative data between developed and developing countries.

Author Contributions: Conceptualization, D.S.C. \& J.Y.P.; methodology \& formal analysis, D.S.C \& J.Y.P.; investigation \& data curation, D.S.C.; writing —original draft preparation, D.S.C; writing — review and editing, J.Y.P.; supervision \& project administration, C.S.S. All authors have read and approved the final manuscript.

Funding: This paper was supported by Joongbu University Research \& Development Fund in 2019.

Conflicts of Interest: The authors declare no conflict of interest.

\section{Appendix A}

Table A1. Criteria of Technology Startups.

\begin{tabular}{|c|c|c|}
\hline Type & Criteria & Source \\
\hline \multirow{3}{*}{$\begin{array}{c}\text { Level of } \\
\text { Technology }\end{array}$} & $\begin{array}{l}\text { Manufacturing: the level of technology } \\
\text { High-tech industries: medical substances and } \\
\text { pharmaceuticals, electronics, computers, multimedia, } \\
\text { communications, optics and watches aircraft, } \\
\text { spaceship and parts manufacturing business } \\
\text { Technology Industries: chemicals and chemicals } \\
\text { (excluding medicines), electrical equipment, other } \\
\text { machinery and equipment, cars and trailers, rail and } \\
\text { other transport equipment (except aircraft) }\end{array}$ & \\
\hline & $\begin{array}{l}\text { Other industries: knowledge-intensive industrial } \\
\text { classification; total construction/construction by } \\
\text { full-time job, the publishing/video/audio record } \\
\text { production/distribution industry, the } \\
\text { broadcasting/communication industry; computer } \\
\text { programming, system integration and management, } \\
\text { the information service/financing/insurance and } \\
\text { pension; financial and insurance-related services; } \\
\text { R\&D/professional services; architectural technology, } \\
\text { engineering, and other science and technology } \\
\text { services; other professional, scientific and technical } \\
\text { services, creative, artistic and leisure-related services, } \\
\text { sports and entertainment services. }\end{array}$ & $\begin{array}{c}\text { OECD, Small and Medium } \\
\text { Business Administration (SMBA), } \\
\text { The Bank of Korea, KBIZ [50] }\end{array}$ \\
\hline & Intangible asset ratio above average & [18] \\
\hline $\begin{array}{l}\text { Status of } \\
\text { Startups }\end{array}$ & Company age less than 7 years & $\begin{array}{c}\text { Small and Medium Business } \\
\text { Administration (SMBA), Startup } \\
\text { Support Act. }\end{array}$ \\
\hline
\end{tabular}

\section{References}

1. Bollinger, L.; Hope, K.; Utterback, J.M. A review of literature and hypotheses on new technology-based firms. Res. Policy 1983, 12, 1-14. [CrossRef] 
2. Bailetti, T. Technology Entrepreneurship: Overview, Definition, and Distinctive Aspects. Technol. Innov. Manag. Rev. 2012, 2, 5-12. [CrossRef]

3. Candi, M.; Saemundsson, R. Exploring the relationship between aesthetic design as an element of new service development and performance. J. Prod. Innov. Manag. 2011, 28, 536-557. [CrossRef]

4. Fritsch, M.; Mueller, P. The effects of new business formation on regional development over time. Reg. Stud. 2004, 38, 961-975. [CrossRef]

5. Acs, Z.J.; Mueller, P. Employment effects of business dynamics: Mice, Gazelles, and Elephants. Small Bus. Econ. 2008, 30, 85-100. [CrossRef]

6. Pyka, A. Dedicated innovation systems to support the transformation towards sustainability: Creating income opportunities and employment in the knowledge-based digital bioeconomy. J. Open Innov. Technol. Mark. Complex. 2017, 3, 27. [CrossRef]

7. Thurik, A.R.; Carreed, M.A.; Stelbe, A.; Audretsch, D.B. Does self-employment reduce unemployment? J. Bus. Ventur. 2008, 23, 673-686. [CrossRef]

8. Decker, R.; Haltiwanger, J.; Jarmin, R.; Miranda, J. The Role of Entrepreneurship in US Job Creation and Economic Dynamism. J. Econ. Perspect. 2014, 28, 3-24. [CrossRef]

9. Cooper, A.C. Spin-offs and technical entrepreneurship. IEEE Trans. Eng. Manag. 1971, 18, 2-6. [CrossRef]

10. Kim, J.H.; Yoon, S.J.; Ahn, J.K. An Empirical Analysis of Characteristics and Job Creations in Technology-based Start-ups. Korea Rev. Appl. Econ. 2015, 17, 167-193.

11. Keynes, J.M. The General Theory of Employment, Interest and Money; Macmillan: London, UK, 1936.

12. Cho, H.; Park, J.Y.; Sung, C.S. The Study on the Difference in Corporate Performance and Employment Outcomes According to the Results of Equity-Based Crowdfunding Investment. J. Open Innov. Technol. Mark. Complex. 2019, 5, 83. [CrossRef]

13. Lee, D.J.; Lee, Y.B.; Kim, J.W. The Impact of New Firm Formation on Regional Employment Change in Korea. Korean Small Bus. Rev. 2011, 33, 73-92.

14. Cho, D.H. Outcomes of Employment Creation and Policy Tasks of Start-up Firms. Ind. Res. Inst. Res. Proj. 2014, 732, 1-159.

15. Anker, R.; Chernyshev, L.; Egger, P.; Mehran, F.; Ritter, J.A. Measuring decent work with statistical indicators. Int. Labour Rev. 2003, 142, 147-177. [CrossRef]

16. Bescond, D.; Chataignier, A.; Mehran, F. Seven indicators to measure decent work: An international comparison. Int. Labour Rev. 2003, 142, 179-211. [CrossRef]

17. Kim, J.W. Is the quality of employment improving? Korea Labor Inst. Labor Rev. 2016, 9, $20-41$.

18. Schumpeter, J.A. The Theory of Economic Development: An Inquiry Into Profits, Capital, Credit, Interest, and the Business Cycle; Harvard University Press: Cambridge, UK, 1934.

19. Pianta, M. Innovation and Employment. In Handbook of Innovation; Fagerberg, J., Mowery, D.C., Eds.; Oxford University Press: New York, NY, USA, 2003.

20. Gyeke-Dako, A.; Oduro, A.D.; Turkson, F.E.; Baffour, P.T.; Abbey, E. The Effect of Technological Innovation on the Quantity and Quality of Employment in Ghana. Swiss Programme Res. Glob. Issues Dev. 2016, 9, 1-36.

21. Harrison, R.; Jaumandreu, J.; Mairesse, J.; Peters, B. Does innovation stimulate employment? A firm-level analysis using comparable micro-data from four European countries. Int. J. Ind. Organ. 2014, 35, $29-43$. [CrossRef]

22. Na, K.; Kang, Y.H. Relations between Innovation and Firm Performance of Manufacturing Firms in Southeast Asian Emerging Markets: Empirical Evidence from Indonesia, Malaysia, and Vietnam. J. Open Innov. Technol. Mark. Complex. 2019, 5, 98. [CrossRef]

23. Aldieri, L.; Vinci, C.P. Innovation effects on employment in high-tech and low-tech industries: Evidence from large international firms within the triad. Eurasian Bus. Rev. 2018, 8, 229-243. [CrossRef]

24. Gassler, H. The regional variation of new technology-based firms in Austria. In Proceedings of the 38th European Regional Science Association Congress, Vienna, Austria, 28 August-1 September 1998.

25. Klofsten, M.; Jones-Evans, D. Comparing academic entrepreneurship in Europe-the case of Sweden and Ireland. Small Bus. Econ. 2000, 14, 299-309. [CrossRef]

26. Yun, J.H.J. How do we conquer the growth limits of capitalism? Schumpeterian Dynamics of Open Innovation. J. Open Innov. Technol. Mark. Complex. 2015, 1, 17. [CrossRef]

27. Chen, C.; Chen, Y.; Hsu, P.H.; Podolski, E.J. Be nice to your innovators: Employee treatment and corporate innovation performance. J. Corp. Financ. 2016, 39, 78-98. [CrossRef] 
28. Adhikari, H.P.; Choi, W.; Sah, N.B. That is what friends do: Employee friendliness and innovation. J. Econ. Bus. 2017, 90, 65-76. [CrossRef]

29. Tangian, A. Decent work: Indexing European working conditions and imposing workplace tax. Transf. Eur. Rev. Labour Res. 2009, 15, 527-556. [CrossRef]

30. Uribe-Toril, J.; de Pablo, V. Business and local development: Training as a basic factor to guide the entrepreneur. Intang. Cap. 2013, 9, 644-677. [CrossRef]

31. Lachenmaier, S.; Rottmann, H. Effects of innovation on employment: A dynamic panel analysis. Int. J. Ind. Organ. 2011, 29, 210-220. [CrossRef]

32. Fitzenberger, B.; Franz, W. Industry-level wage bargaining: A partial rehabilitation-The german experience. Scotish J. Political Econ. 1999, 46, 437-457. [CrossRef]

33. Hamermesh, D.S. Labor Demand; Princeton University Press: Princeton, NJ, USA, 1993.

34. Frydman, C.; Papanikolaou, D. In search of ideas: Technological innovation and executive pay inequality. J. Financ. Econ. 2018, 130, 1-24. [CrossRef]

35. Hong, S.M.; Min, C.G.; Park, K.B.; Kim, H.J.; Hong, J.I.; Hwang, S.K.; Choi, C.G.; Kim, H.N. The study of the effect of technology innovation on employment creation in science and engineering sector. Korea Inst. Sci. Technol. Inf. 2010, 20, 1-273.

36. Castillo, V.; Maffioli, A.; Rojo, S.; Stucchi, R. The effect of innovation policy on SMEs' employment and wages in Argentina. Small Bus. Econ. 2014, 42, 387-406. [CrossRef]

37. Yang, Y.; Shao, X. Understanding industrialization and employment quality changes in China: Development of a qualitative measurement. China Econ. Rev. 2018, 47, 274-281. [CrossRef]

38. Jaumandreu, J. Does innovation spur employment. A firm-level analysis using Spanish CIS data. Univ. Carlos Madr. 2003, 17, 813-839.

39. Acharya, V.V.; Baghai, R.P.; Subramanian, K.V. Labor laws and innovation. J. Law Econ. 2013, 56, 997-1037. [CrossRef]

40. Chang, X.; Fu, K.; Low, A.; Zhang, W. Non-executive employee stock options and corporate innovation. J. Financ. Econ. 2015, 115, 168-188. [CrossRef]

41. Lin, C.; Lin, P.; Song, F.M.; Li, C. Managerial incentives, CEO characteristics and corporate innovation in China's private sector. J. Comp. Econ. 2011, 39, 176-190. [CrossRef]

42. Frick, W. Treating Workers Well Leads to More Innovation. Harvard Business Review. 3 November 2015. Available online: https://hbr.org/2015/11/when-treating-workers-well-leads-to-more-innovation (accessed on 30 June 2019).

43. Korea Labor Institution, Workplace Panel Survey. 2015. Available online: https://www.kli.re.kr/wps/index.do (accessed on 30 June 2019).

44. Korea Small Business Startup Support Act. Ministry of SMEs and Startups, 2009. Available online: https://www.mss.go.kr/site/eng/02/10203000000002016111504.jsp (accessed on 30 June 2019).

45. International Organization of Employers, European Union. 2019. Available online: https://www.ioe-emp. org/en/international-organisations/european-union/ (accessed on 30 June 2019).

46. Hagedoorn, J.; Cloodt, M. Measuring innovative performance: Is there an advantage in using multiple indicators? Res. Policy 2003, 32, 1365-1379. [CrossRef]

47. Ugur, M.; Awaworyi Churchill, S.; Solomon, E. Technological innovation and employment in derived labour demand models: A hierarchical meta-regression analysis. J. Econ. Surv. 2018, 32, 50-82. [CrossRef]

48. Bogliacino, F. Innovation and employment: A firm-level analysis with European R\&D Scoreboard data. EconomiA 2014, 15, 141-154.

49. Ertugrul, M. Employee-friendly acquires and acquisition performance. J. Financ. Res. 2013, 36, 347-370. [CrossRef]

50. Lee, J.H.; Lee, H.Y. Effects of Knowledge-based Startups on Employment Growth. J. Econ. Geogr. Soc. Korea 2017, 20, 137-157.

(C) 2020 by the authors. Licensee MDPI, Basel, Switzerland. This article is an open access article distributed under the terms and conditions of the Creative Commons Attribution (CC BY) license (http://creativecommons.org/licenses/by/4.0/). 